\title{
Leaching Behavior of Particulate Plutonium Oxide
}

\author{
S. T. Kosiewicz \\ R. C. Heaton
}

\section{DISCLAIMEK}

\begin{abstract}
This report was prepared as an account of work sponsored by an agency of the United States Government. Neither the United States Government nor any agency thereof, nor any of their employees, makes any warranty, express or implied, or assumes any legal liability or respons:bility for the accuracy, completeness, or usefulness of any information, apparatus, product, or process disclosed, or represents that its use would not infringe privately owned rights. Reference herein to any specific commercial produst, process, or service by trade name, trademark, manufacturer, or otherwise does not necessarily sonstitute or imply its endorsement, recommendation, or favoring by the United States Government or any agency thereof. The views and opirions of authors expressed herein do not necessarily state or reflect those of the United States Government or any agency thereof.
\end{abstract}




\title{
LEACHING BEHAVIOF OF PARTICULATE PLUTONIUM OXIDE
}

\author{
by
}

\author{
S. T. Kosiewicz and R. C. Heaton
}

\begin{abstract}
Different size cuts of ${ }^{238} \mathrm{PuO}_{2}$ particles were mixed with deionized water at two temperatures in a shaker bath. The gross plutonium concentration in the water was measured, as well as that portion of the plutonium retained on a $0.1-\mu \mathrm{m}$ pore filter. The concentration of the plutonium released was primarily a function of the surface area of the particles. The release rate of plutonium into the water for the size cut with particles having diameters between 30 and $20 \mu \mathrm{m}$ was $3 \mathrm{ng} / \mathrm{m}^{2} / \mathrm{s}$; this rate is within the range observed in past experiments involving aquatic environments. The amount of material retained by the $0.1-\mu \mathrm{m}$ filters decreased with increasing time, suggesting that size reduction or removal processes occurred.
\end{abstract}

\section{INTRODUCTION}

Plutonium oxide heat sources are used in the space program to supply power for spacecraft and satellites on long-term missions throughout the solar system. These sources and their containments are designed with great care to minimize the possibility of plutonium being released into the environment. Nevertheless, should a spacecraft containing one of these heat sources reenter the earth's atmosphere, or should it suffer a launch abort, a significant amount of plutonium could be re-leised to the environment.

For many years the Los Alamos National Laboratory has been testing containment systems and studying the environm:ental behavior of plutonium oxide in order to generate data for risk assessments and safety analyses. An undersianding of the mobilization and transport mechanisms for environmental plutonium not only will lead to more accurate risk assessments but also will substantially reduce the time and effor required to do such analyses. Accordingly, we have initiated a seiies of experiments to identify the major factors controlling plutonium release from plutonium oxide sources into water.' This report describes an experiment in which plutonium dioxide particles of different sizes were placed in contact with deionized water at two temperatures to observe, cver 4 weeks, the plutonium release.

\section{OBJECTIVE}

The purpose of this experiment was to iaentify the characteristics that most strongly affect the rates of plutonium release from plutonium oxide particles into vater and to determine the functional relationships among the independent and dependent variables. This experiment was designed to determine whether plutonium release depends primarily on the mass of the source, the surface area of the source, or both. A secondary objective was to gain experience with particle leaching techniques before designing more sophisticated efforts.

\section{EXPERIMENTAL. WORK}

\section{Source Material}

The plutonium dioxide source materials were fragments obtained from several ${ }^{238} \mathrm{PuO}_{2}$ pellets that had been used for impact tests. The isotopic compositions of 
the pellets varied slightly, but they were nominally $83 \%$ ${ }^{238} \mathrm{Pu}$ with a sperific activity of $14.2 \mathrm{Ci} / \mathrm{g}$. Table $\mathrm{I}$ shows the isotopic composition of one pellet. Four particle size ranges were used in these experiments. The particles in the largest size range passed through a sieve with a 420 $\mu \mathrm{m}$-diam opening but were retained on a 125 - $\mu \mathrm{m}$-diam sieve. This sieve cut was designated as $-420 /+125 \mu \mathrm{m}$.

Using the same designation system, we determined the three other size ranges: $-125 /+74,-74 /+44$, and $-30 /+20 \mu \mathrm{m}$. We did not use particles smaller than $20-$ $\mu \mathrm{m}$ diam because we wanted to avoid working with particles that approached the respirable range of approximately $5 \mu \mathrm{m}$ or less. Even though the different particle size cuts were obtained by sieving, the samples were again wet-sieved with an ultrasonic bath less than $24 \mathrm{~h}$ before the leaching experiments began. This step removed extremely fine particles from the samples. For each individual leaching experiment, $0.5 \mathrm{~g}$ of plutonitum dioxide of a particular sieve cut was weighed and transferred (in a closed glovebox) to a 125-mL Erlenmeyer flask containing $50.00 \mathrm{~mL}$ of water that had been purified by a Millipore ion-exchange system.

For the sieve cuts with diameters of $-125 /+74$, $-74 /+44$, and $-30 /+20 \mu \mathrm{m}$, dry controls of the plutonium oxide were prepared to determine if the medium affected size reduction. For the controls, $0.5 \mathrm{~g}$ of dry $\mathrm{PuO}_{2}$ of the appropriate sieve cur was weighed into a bottle and retained in the glovebox. When the experiments with the deionized water were completed, both the wet samples and the dry controls were resieved.

We calculated surface areas, assuming spherical paricles whose diameters corresponded to the midpoint of the sieve cut range. A density of $11 \mathrm{~g} / \mathrm{cm}^{3} \mathrm{u}$ as taken for $\mathrm{PuO}_{2}$.

\section{Equipment}

The Erlenmeyer flasks containing the plutonium dioxide paricles and deionized water were placed in an orbital water bath shaker (Laboratory Line Instruments. Inc., Model 3535). The shaker was adjusted to 1 to 2

\begin{tabular}{|c|c|}
\hline Isotope & $\begin{array}{c}\text { A burrdance } \\
(\%)\end{array}$ \\
\hline${ }^{238} \mathrm{Pu}$ & 83.29 \\
\hline${ }^{239} \mathrm{Pu}$ & 14.09 \\
\hline${ }^{240} \mathrm{Pu}$ & 2.06 \\
\hline${ }^{241} \mathrm{Pu}$ & 0.4 \\
\hline${ }^{242} \mathbf{P u}$ & 0.16 \\
\hline
\end{tabular}

rpm; at this speed, the water was swirled, but with no apparent tumbling of the plutonium dioxide particles. Because these experiments lasted extended periods, a sheet of polyethylene film was placed over the water bath to reduce evaporation. To eliminate evaporation of deionized water from the Erlenmeyer flasks, the flasks were closed with hollow plastic stoppers with small holes tn allow radiolytically generated gases to escape. A second but larger hollow plastic stopper was inverted and then placed over the first to prevent condensate from accumulating in the first stopper.

Two experiments were performed, one at $20^{\circ} \mathrm{C}$ (ambient room temperature) and the other at $37^{\circ} \mathrm{C}$ (used in other aquatic experiments). ${ }^{2,3}$ At the higher temperature, we experienred occasional difficulties with a safety cutoff on the shaker that turned off the heater in the bath. Thus the iemperature control was less than adequate in the $37^{\circ} \mathrm{C}$ experiment.

\section{Samples}

To obtain samples for $\mathrm{pH}$ determination, filtration, and scintillation counting. the Erlenmeyer flasks were removed from the shaker bath and allowed to stand for several minutes so large particles could settle out of the zone of solution to be sampled. Sample aliquots ( 10 to $100 \mu \mathrm{L}$ ) were then withdrawn from the top of the liquid layer with an Eppendorf pipette. The initial samples were done in duplicate to ascertain sample-to-sample variation. This dupication was discontinued after several samplings because the reproducibility was acceptable.

At the beginning of the experiment, samples were removed from the flasks more frequently than at the end. For example, in the $20^{\circ} \mathrm{C}$ experiment, the first two samples were taken 1 day apart, whereas the last two were taken I week apart; we had expected any observed changes to be more rapid at the beginning of the experiment. After 4 weeks, when sampling was discontinued and the $\mathrm{PuO}_{2}$ samples were resieved, the experiment was completed.

Samples for scintillation counting to determine the gross plutonium concentration in the water were transferred directly into scintillation vials. Scintillation cocktail was added to the vials, which then were counted in a Packard scintillation counter. The samples for filtration were filtered by vacuum thıough $0.1-\mu \mathrm{m}$ Nuclepore polycarbonate filters. The filters were dissolved in Protosol tissue solubilizer, and the amount of plutonium retained on them was determined by scintillation counting.

The $\mathrm{pH}$ of the solutions was measured with shortrange $\mathrm{pH}$ papers. This methed was preferred over glass electrodes because the $\mathrm{pH}$ values of each flask could be determined with less sample and without the risk of cross-contaminating the flasks. 


\section{RESULTS AND DISCUSSION}

Data for the lower temperature $\left(20^{\circ} \mathrm{C}\right)$ experiments are summarized in Tables II to V. The plutonium concentrations observed in the leachates are plotted versus time in Fig. i. One of the most obvious features of these results is that the smallest particles release significaritly higher concentrations of plutonium into the deionized water. However, the three other size ranges released similar amounts of plutonium. Because the mass of plutonium oxide used in each sample was the same, it might appear at first that the sample mass determines the overall release rate. However, the data for the smallest size cut are inconsistent with this concept. Qualitatively, the data trends are consistent with a surface area dependence, with the smaller part:cles yielding increasingly higher release rates. Quantitatively, the results are not quite so clear. The pluto- nium concentrations normalized to the surface area are plotted in Fig. 2. Although the curves for the largest three particle size cuts diverge more in Fig. 2 than they do in Fig. 1, the normalization has the effect of placing the curve for the smallest size cut squarely among the other three. Thus the plutonium release per unit area is a more consistent value over the entire data set than is the unnormalized release rate.

For all four sieve cuts, the plutonium concentration in the water increases approximately linearly with time over the experiment. This linear concentration curve inplies a constant release rate over the experiment equal to the slope of the curve. The slopes of the curves in Fig. 2, derived by least squares fits of the data, range from 1.5 to $4.8 \mathrm{ng} / \mathrm{m}^{2} / \mathrm{s}$. These fall within the limits of uncertainty nesulting from the surface area calculations. Thus the normalized curves are probably not significantly different from each other. In fact. the curve for

\begin{tabular}{|c|c|c|c|c|c|c|}
\hline \multirow{2}{*}{$\begin{array}{l}\text { Elapsed } \\
\text { Time } \\
\text { (Days) }\end{array}$} & \multirow{2}{*}{$\begin{array}{l}\text { Sample } \\
\text { Size } \\
(\mu \mathrm{L}) \\
\end{array}$} & \multicolumn{3}{|c|}{ Pu Concentration } & \multicolumn{2}{|c|}{ Pu Retained on $0.1-\mu \mathrm{m}$ Filter } \\
\hline & & pH & $(\mu \mathrm{Ci} / \mathrm{mL})$ & $\left(\mu \mathrm{Ci} / \mathrm{mL} / \mathrm{m}^{2}\right)^{\mathbf{n}}$ & $(\mu \mathrm{Ci} / \mathrm{mL})$ & (\% of Total) \\
\hline \multirow[t]{2}{*}{0} & 100 & - & 6.5 & $5.4 \times 10^{2}$ & 4.2 & 6.2 \\
\hline & & & & & 3.7 & 57 \\
\hline \multirow[t]{2}{*}{1} & 100 & 4 & 12 & $1.0 \times 10^{3}$ & 1.5 & 13 \\
\hline & & & & & 1.3 & 11 \\
\hline \multirow[t]{2}{*}{4} & 10 & 4 & 6 & $5.0 \times 10^{2}$ & 1.5 & 25 \\
\hline & & & & & 1.6 & 26 \\
\hline 9 & 10 & 4 & 18 & $1.5 \times 10^{3}$ & 5.4 & 30 \\
\hline 15 & 10 & 4 & 20 & $2.7 \times 19^{3}$ & 2.7 & 14 \\
\hline 23 & 10 & 4 & 31 & $2.6 \times 10^{3}$ & 14 & 45 \\
\hline 28 & 10 & 4 & 27 & $2.2 \times 10^{3}$ & 5 & 18 \\
\hline
\end{tabular}

"Surface area calculated to be $1.2 \times 10^{-2} \mathrm{~m}$;

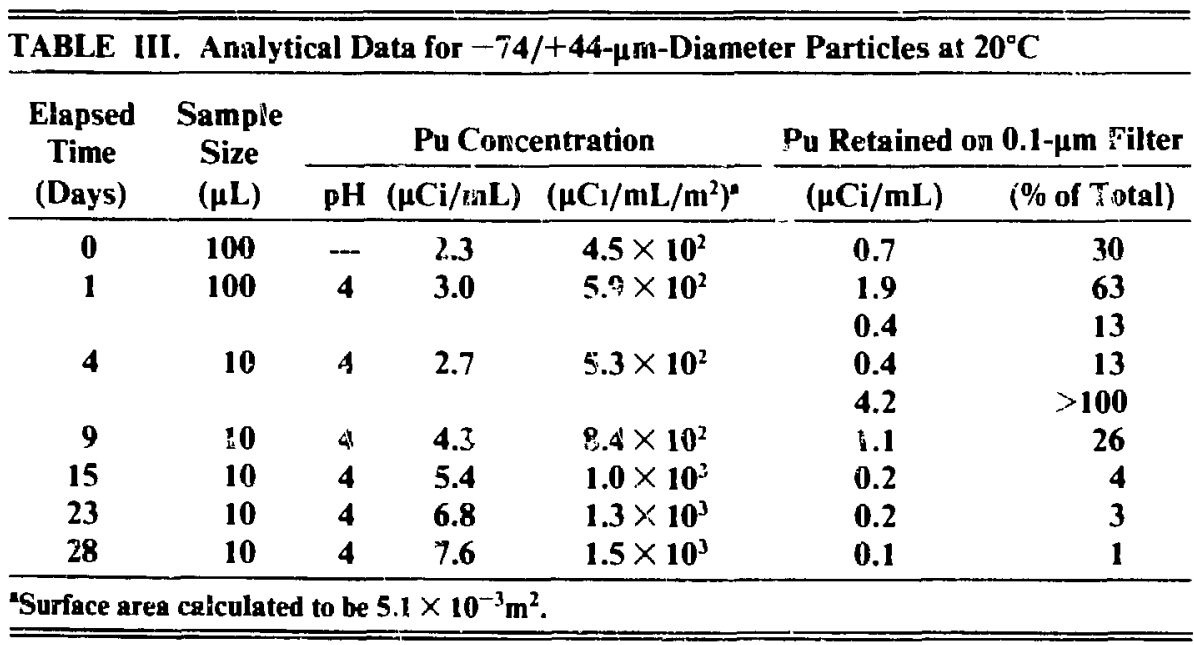




\begin{tabular}{|c|c|c|c|c|c|c|}
\hline \multirow{2}{*}{$\begin{array}{c}\text { Elapsed } \\
\text { Time } \\
\text { (Days) }\end{array}$} & \multirow{2}{*}{ 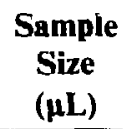 } & \multicolumn{3}{|c|}{ Pu Concentration } & \multicolumn{2}{|c|}{ Pu Retained on 0.1- $\mu \mathrm{m}$ Filter } \\
\hline & & $\mathbf{p H}$ & $(\mu \mathrm{Ci} / \mathrm{mL})$ & $\left(\mu \mathrm{Ci} / \mathrm{mL} / \mathrm{m}^{2}\right)^{a}$ & $(\mu \mathrm{Ci} / \mathrm{mL})$ & (\% of Total) \\
\hline $\mathbf{0}$ & 100 & - & 1.4 & $5.6 \times 10^{2}$ & --. & -- \\
\hline 1 & 100 & 4 & 2.3 & $9.2 \times 10^{2}$ & $\begin{array}{l}0.8 \\
0.5\end{array}$ & $\begin{array}{l}35 \\
22\end{array}$ \\
\hline 4 & 10 & 4 & 2.4 & $9.6 \times 10^{2}$ & $\begin{array}{l}0.4 \\
0.3\end{array}$ & $\begin{array}{l}17 \\
13\end{array}$ \\
\hline 9 & 10 & 4 & 3.9 & $1.6 \times 10^{3}$ & 0.3 & 9 \\
\hline 15 & 10 & 4 & 4.9 & $2.0 \times 10^{3}$ & 0.2 & 4 \\
\hline 23 & 10 & 4 & 5.8 & $2.3 \times 10^{3}$ & 0.1 & 2 \\
\hline 28 & 10 & 4 & 6.8 & $2.7 \times 10^{3}$ & 0.1 & 2 \\
\hline
\end{tabular}

'Surface area calculated to be $2.5 \times 10^{-3} \mathrm{~m}^{2}$.

\begin{tabular}{|c|c|c|c|c|c|c|}
\hline \multirow{2}{*}{$\begin{array}{c}\text { Elapsed } \\
\text { Time } \\
\text { (Days) }\end{array}$} & \multirow{2}{*}{$\begin{array}{c}\text { Sample } \\
\text { Size } \\
(\mu \mathrm{L})\end{array}$} & \multicolumn{3}{|c|}{ Pu Concentration } & \multicolumn{2}{|c|}{ Pu Retained or 0.1- $\mu \mathrm{m}$ Filter } \\
\hline & & pH & $(\mu \mathrm{Ci} / \mathrm{mL})$ & $\left(\mu \mathrm{Ci} / \mathrm{mL} / \mathrm{m}^{2}\right)^{\mathrm{a}}$ & $(\mu \mathrm{Ci} / \mathrm{mL})$ & (\% of Total) \\
\hline $\mathbf{0}$ & 100 & -- & 1.3 & $1.1 \times 10^{3}$ & -- & -- \\
\hline 1 & 100 & 4 & 1.8 & $1.5 \times 10^{3}$ & $\begin{array}{l}1.9 \\
1.6\end{array}$ & $\begin{array}{r}>100 \\
89\end{array}$ \\
\hline 4 & 10 & 4 & 2.0 & $1.7 \times 10^{3}$ & $\begin{array}{l}0.7 \\
0.9\end{array}$ & $\begin{array}{l}35 \\
45\end{array}$ \\
\hline 9 & 10 & 4 & 2.8 & $2.3 \times 10^{3}$ & 0.4 & 14 \\
\hline 15 & 10 & 4 & 3.7 & $3.1 \times 10^{3}$ & 0.2 & 5 \\
\hline 23 & 10 & 4 & 4.5 & $3.8 \times 10^{3}$ & 3.6 & 80 \\
\hline 28 & 10 & 4 & 5.0 & $4.2 \times 10^{3}$ & 0.4 & 8 \\
\hline
\end{tabular}

Surface area calculated to be $1.2 \times 10^{-3} \mathrm{~m}^{2}$.

the smallest diameter particles $(-30 /+20-\mu \mathrm{m}$ cut $)$ falls in the middle of the set of curves even though these particles have the highest plutonium relcase rate. Therefore, we suggest that the plutonium release rates depend primarily on the surface areas of the particles.

A representative release rate for this set of curves, that of the $-30 /+20-\mu \mathrm{m}$ sieve cut, is approximately 3 $\mathrm{ng} / \mathrm{m}^{2} / \mathrm{s}$. This rate compares favorably with the 3.9 $\mathrm{ng} / \mathrm{m}^{2} / \mathrm{s}$ observed for warm fresh water $\left(37^{\circ} \mathrm{C}\right)$ in a previous aquarium experiment, ${ }^{3}$ but it is less than the 10 to $30 \mathrm{ng} / \mathrm{m}^{2} / \mathrm{s}$ observed for cold $\left(10^{\circ} \mathrm{C}\right)$ fresh water in the same experiment. In a related experiment that used large (40-g) sources in a vigorously stirred environment, release rates of 17 and $95 \mathrm{ng} / \mathrm{m}^{2} / \mathrm{s}$ were observed for warm and cold fresh water respectively. ${ }^{2}$ In another case that examined the "solubility" of plutonium oxide particulates, the release rates were slightly tigher than in the current study $\left(16.8\right.$ to $45.0 \mathrm{ng} / \mathrm{m}^{2} / \mathrm{s}$ in fresh water and 3.3 to $13.1 \mathrm{ng} / \mathrm{m}^{2} / \mathrm{s}$ in normal saline). ${ }^{4}$ Studies of the apparent release rate in $1 \mathrm{M}$ perchloric acid yielded values between 0.73 and $9.5 \mathrm{ng} / \mathrm{m}^{2} / \mathrm{s}$, which span the range observed in the present experiment. ${ }^{5}$ Thus, the release rates observed in the present experiment fall within the range of values derived from other studies, although the current values are at the lower end of this range. The fact that the release rates for these experiments agree as well as they do when normalized to surface area is an additional argument supporting the hypothesis that surface area is a primary factor controlling the release rate.

Evidence in the literature indicates that plutonium oxide particles, particularly those highly enriched in ${ }^{238} \mathrm{Pu}$, undergo spontaneous fragmentation to generate significant quantities of much smaller particles. ${ }^{6}$ To determine the importance of this effect, the plutonium oxide samples were resieved immediately after the leaching measurements. Over the 4 weeks of the experiment, approximately 1 to $4 \%$ of the sample mass size 


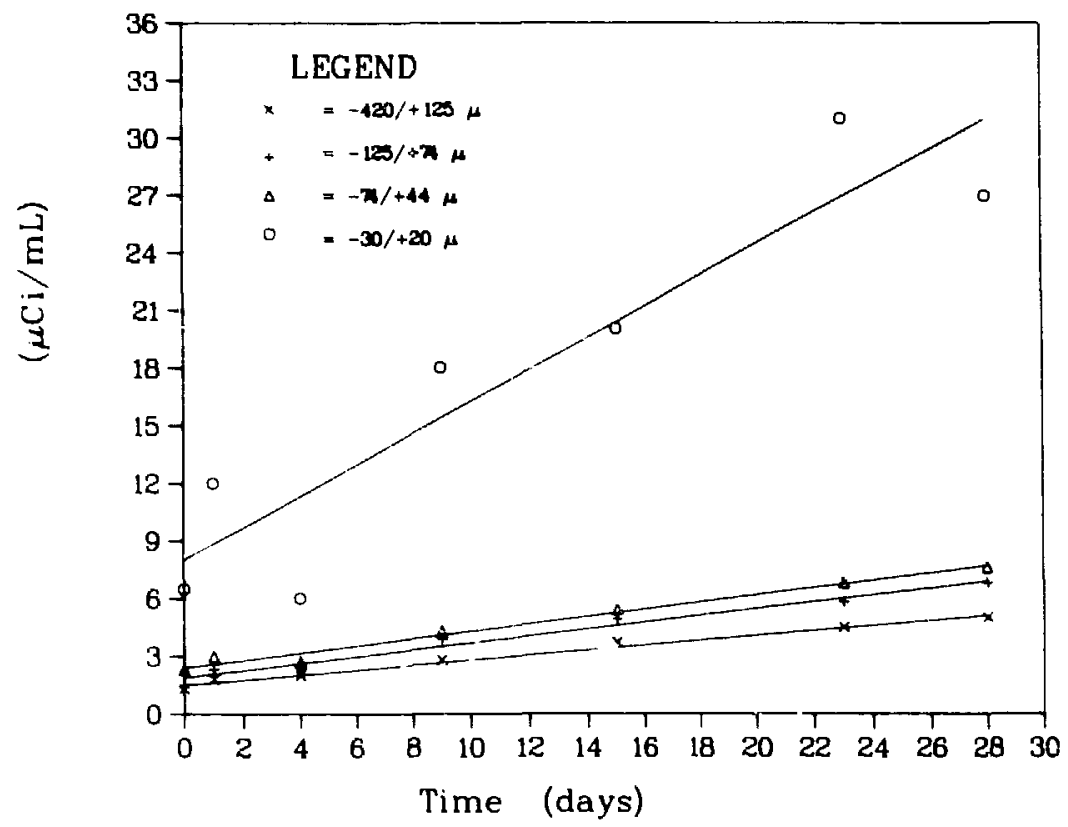

Fig. 1. Aqueous plutonium concentration versus time for leaching experiments at $20^{\circ} \mathrm{C}$.

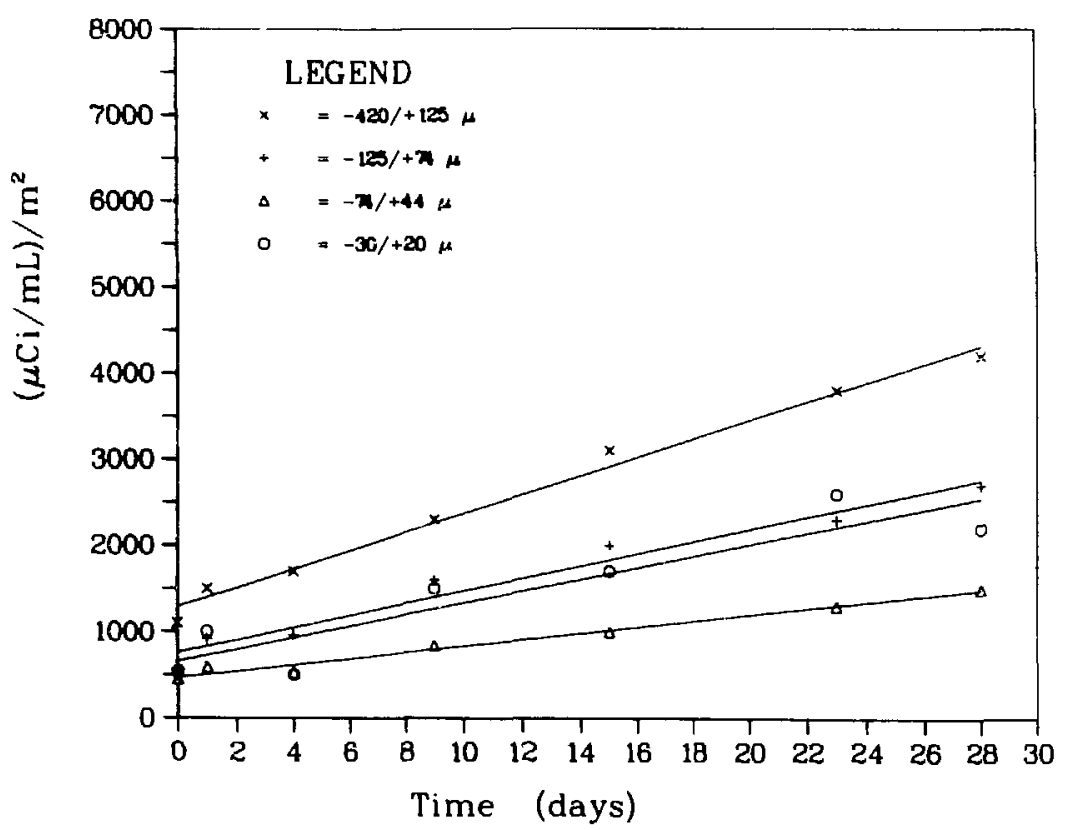

Fig. 2. Aqueous plutonium concentration normalized to the source surface area versus time for leaching experiments at $20^{\circ} \mathrm{C}$. 
decreased enough to allow it to pass through the sieve that had previously retained it. There was no apparent correlation between this percentage and the initial particle size range. In addition, we found no apparent difference in size reduction between the control samples that were stored in a dry condition and the wet plutonium dioxide particles that were resieved. This finding suggests that the observed size reduction is independent of the medium and that any effect of the leaching medium on the rate of spontaneous fragmentation of the sample particles should not be of concern in interpreting the results of this experiment.

The filtration data in Tables II to $\mathrm{V}$ suggest that for each particle size range there is a decrease in the percentage of plutonium particles retained on the $0.1-\mu \mathrm{m}$ filters with increasing time. This decreased percentage results from both an increase in the total amount of plutonium in the liquid phase and also a decrease in the amount of plutonium retained on the filtration membranes. The increasing plutonium concentration in the liquid phase is easily explained by the continued release of plutonium from the plutonium oxide sample into the water. However, to account for the decreasing filter retention, the existing particles in the bulk liquid phase either must undergo some size degradation process so they pass through the filter, or they must otherwise be removed from the liquid phase so they are no longer part of the simple aliquot. Which of these two processes is responsible for the decreasing filter retention cannot be determined from this experiment. A considerable degree of scatter occurs among the filtration data points, which may derive from nonstatistical sampling of plutonium oxide particles, both in the gross sample and on the filters, and can lead to large variations in the sample count. This problem may be avoided in the future by examining the filtrate directly rather than by calculating the difference between the gross plutonium count and the corresponding filter residue.
Data for the $37^{\circ} \mathrm{C}$ experiments are tabulated in Tables VI to IX. In obtaining these data, we experienced some sampling difficulties related to the higher temperature of the experiment. When the flasks were removed from the shaker bath and allowed to stand, they cooled considerably. During this cooling process, convection currents may have formed that could have circulated plutonium oxide particles into the sampling zone in a nonreproducible way. Such an occurrence would cause anomalously high and irreproducible concentration measurements. Indeed, Fig. 3 shows more scatter among these data than among those in Fig. $2\left(20^{\circ} \mathrm{C}\right)$. Furthermore, the apparently anomalous points are high. An additional complication occurred because a temperature controller in the temperature bath malfunctioned. Because of these factors, we do not have a great deal of confidence in the results of this portion of the experiment. The amounts of plutonium observed in the water for the $37^{\circ} \mathrm{C}$ experiment were similar to those in the $20^{\circ} \mathrm{C}$ experiment. Although these results do not seem to corroborate previous experiments, which revealed higher release rates in colder media, ${ }^{2.3}$ we do not attach much significance to this observation for the current experiment.

\section{CONCLUSIONS}

The release rate of plutonium from plutonium dioxide particles into deionized water was substantially higher for the smallest diameter particles when similar masses of materials were used. After the release rates were normalized to approximate surface areas, they were the same within experimental uncertainties, clearly indicating that the plutonium release rates may depend primarily on the surface area of the solid source. The amount of material retained by the $0.1-\mu \mathrm{m}$ filters decreased with time. Therefore, a size reduction process

\begin{tabular}{|c|c|c|c|c|c|c|}
\hline \multirow{2}{*}{$\begin{array}{c}\text { Elapsed } \\
\text { Time } \\
\text { (Days) }\end{array}$} & \multirow{2}{*}{$\begin{array}{c}\text { Sample } \\
\text { Size } \\
(\mu \mathrm{L})\end{array}$} & \multicolumn{3}{|c|}{ Pu Concentration } & \multicolumn{2}{|c|}{ Pu Retained on 0.1- $\mu \mathrm{m}$ Filter } \\
\hline & & pHI & $(\mu \mathrm{Ci} / \mathrm{mi})$ & $\left(\mu \mathrm{Ci} / \mathrm{mL} / \mathrm{m}^{2}\right)^{\mathrm{a}}$ & $(\mu \mathrm{Ci} / \mathrm{mL})$ & ( $\%$ of Total) \\
\hline $\mathbf{0}$ & 10 & 4 & 5.4 & $4.5 \times 10^{2}$ & 2.8 & 52 \\
\hline 1 & 10 & 4 & 8.1 & $6.8 \times 10^{2}$ & 3.0 & 37 \\
\hline 2 & 10 & 4 & 8.1 & $6.8 \times 10^{2}$ & 2.5 & 30 \\
\hline 3 & 10 & 4 & 9.4 & $7.8 \times 10^{2}$ & 2.8 & 30 \\
\hline 6 & 10 & 4 & 12 & $1.0 \times 10^{3}$ & 2.7 & 23 \\
\hline 9 & 10 & 4 & $\mathbb{1 3}$ & $1.1 \times 10^{3}$ & 4.2 & 34 \\
\hline 17 & 10 & 4 & 38 & $3.2 \times 10^{3}$ & 6.8 & 18 \\
\hline 23 & 10 & - & 20 & $1.7 \times 10^{3}$ & 4.3 & 22 \\
\hline 31 & 10 & 4 & 24 & $2.0 \times 10^{3}$ & 3.2 & 13 \\
\hline
\end{tabular}

Surface area calculated to be $1.2 \times 10^{-2} \mathrm{~m}^{2}$. 
TABLE VII. Analytical Data for $-74 /+44-\mu \mathrm{m}$-Diameter Particles at $37^{\circ} \mathrm{C}$

\begin{tabular}{|c|c|c|c|c|c|c|}
\hline \multirow{2}{*}{$\begin{array}{c}\text { Elapsed } \\
\text { Time } \\
\text { (Days) }\end{array}$} & \multirow{2}{*}{$\begin{array}{c}\text { Sample } \\
\text { Size } \\
\text { (pL) }\end{array}$} & \multicolumn{3}{|c|}{ Pu Concentration } & \multicolumn{2}{|c|}{ Pu Retained on 0.1 $\mu \mathrm{m}$ Filter } \\
\hline & & pH & $(\mu \mathrm{Ci} / \mathrm{mL})$ & $\left(\mu \mathrm{Ci} / \mathrm{mL} / \mathrm{m}^{2}\right)^{2}$ & $(\mu \mathrm{Ci} / \mathrm{mL})$ & (\% of Total) \\
\hline $\mathbf{0}$ & 10 & 4 & 2.7 & $5.3 \times 10^{2}$ & 1.1 & 41 \\
\hline $\mathbf{1}$ & 10 & 4 & 4.0 & $7.8 \times 10^{2}$ & 1.7 & 42 \\
\hline 2 & 10 & 4 & 5.0 & $10 \times 10^{2}$ & 1.3 & 26 \\
\hline 3 & 10 & 4 & 4.5 & $8.8 \times 10^{2}$ & 1.6 & 35 \\
\hline 6 & 10 & 4 & 5.4 & $1.0 \times 10^{3}$ & 1.3 & 24 \\
\hline 9 & 10 & 4 & 2.6 & $5.1 \times 10^{2}$ & 0.2 & 9 \\
\hline 17 & 10 & 4 & 2.9 & $5.7 \times 10^{2}$ & 0.4 & 13 \\
\hline 23 & 10 & 4 & 9.4 & $1.8 \times 10^{3}$ & 1.2 & 12 \\
\hline 31 & 10 & 4 & 1.1 & $2.2 \times 10^{3}$ & 1.2 & 11 \\
\hline
\end{tabular}

'Surface area calculated to be $5.1 \times 10^{-3} \mathrm{~m}^{2}$.

TABLE VIII. Analytical Data for $-125 /+74-\mu \mathrm{m}$-Diameter Particles at $37^{\circ} \mathrm{C}$

\begin{tabular}{|c|c|c|c|c|c|c|}
\hline \multirow{2}{*}{$\begin{array}{c}\text { Elapsed } \\
\text { Time } \\
\text { (Days) }\end{array}$} & \multirow{2}{*}{$\begin{array}{c}\text { Sample } \\
\text { Size } \\
\text { (pl) }\end{array}$} & \multicolumn{3}{|c|}{ Pu Concentration } & \multicolumn{2}{|c|}{ Pu Retained on 0.1- $\mu \mathrm{m}$ Filter } \\
\hline & & $\mathbf{p H}$ & $(\mu \mathrm{Ci} / \mathrm{mL})$ & $\left(\mu \mathrm{Ci} / \mathrm{mL} / \mathrm{m}^{2}\right)^{\prime}$ & $(\mu \mathrm{Ci} / \mathbf{m L})$ & (\% of Total) \\
\hline $\mathbf{0}$ & 10 & 4 & 1.5 & $6.0 \times 10^{2}$ & 0.3 & 20 \\
\hline 1 & 10 & 4 & 2.5 & $1.0 \times 10^{3}$ & 0.6 & 23 \\
\hline 2 & 10 & 4 & 2.8 & $1.1 \times 10^{3}$ & 0.4 & 13 \\
\hline 3 & 10 & 4 & 2.8 & $1.1 \times 10^{3}$ & 0.9 & 38 \\
\hline 6 & 10 & 4 & 2.3 & $9.2 \times 10^{2}$ & 0.4 & 19 \\
\hline 9 & 10 & 4 & 2.5 & $1.0 \times 10^{3}$ & 0.2 & 7 \\
\hline 17 & 10 & 4 & 2.6 & $1.0 \times 10^{3}$ & 0.3 & 12 \\
\hline 23 & 10 & $\cdots$ & 3.1 & $1.2 \times 10^{3}$ & 0.3 & 11 \\
\hline 31 & 10 & 4 & 2.1 & $8.4 \times 10^{2}$ & 0.3 & 15 \\
\hline
\end{tabular}

Surface area calculated to be $2.5 \times 10^{-3} \mathrm{~m}^{2}$.

\begin{tabular}{|c|c|c|c|c|c|c|}
\hline \multirow{2}{*}{$\begin{array}{c}\text { Elapsed } \\
\text { Time } \\
\text { (Days) } \\
\end{array}$} & \multirow{2}{*}{$\begin{array}{c}\text { Sample } \\
\text { Size } \\
\text { ( } \mu \text { L) }\end{array}$} & \multicolumn{3}{|c|}{ Pu Concentration } & \multicolumn{2}{|c|}{ Pu Retained on 0.1-um Filter } \\
\hline & & $\mathbf{p H}$ & $(\mu \mathrm{Ci} / \mathrm{mL})$ & $\left(\mu \mathrm{Ci} / \mathrm{mL} / \mathrm{m}^{2}\right)^{n}$ & $(\mu \mathrm{Ci} / \mathbf{m L})$ & (\% of Total) \\
\hline $\mathbf{0}$ & 10 & 4 & 1.8 & $1.5 \times 10^{3}$ & 0.2 & 11 \\
\hline 1 & 10 & 4 & 2.4 & $2.0 \times 10^{3}$ & 0.7 & 29 \\
\hline 2 & 10 & 4 & 2.3 & $1.9 \times 10^{3}$ & 0.3 & 13 \\
\hline 3 & 10 & 4 & 2.7 & $2.2 \times 10^{3}$ & 0.2 & 7 \\
\hline 6 & 10 & 4 & 2.5 & $2.1 \times 10^{3}$ & 0.6 & 24 \\
\hline 9 & 10 & 4 & 7.2 & $6.0 \times 10^{3}$ & 1.6 & 22 \\
\hline 17 & 10 & 4 & 9.0 & $7.5 \times 10^{3}$ & 1.6 & 18 \\
\hline 23 & 10 & --. & 3.7 & $3.1 \times 10^{3}$ & 0.1 & 3 \\
\hline 31 & 10 & 4 & 3.2 & $2.7 \times 10^{3}$ & 0.2 & 6 \\
\hline
\end{tabular}

'Surface area calculated to be $1.2 \times 10^{-3} \mathrm{~m}^{2}$. 


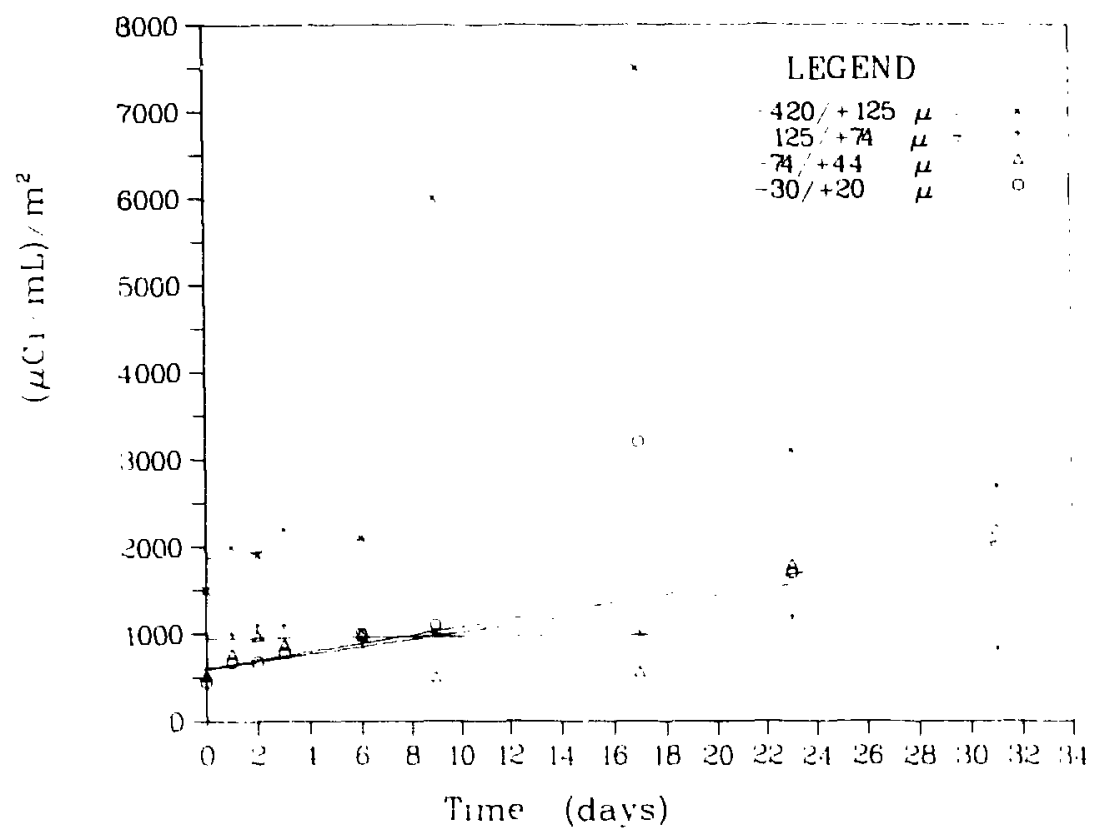

Fig. 3. Aqueous plutontum concentration normalized to the source surface area versus time for leaching experiments at $37^{\circ} \mathrm{C}$

occurred or filterable particles were being removed from the sampled layers of the mixing vessels. Although little or no difference was observed between release rates at $20^{\circ} \mathrm{C}$ and $37^{\circ} \mathrm{C}$, we experienced complications in obtaining the measurements. This observation needs to be confirmed before we draw any definite conclusions concerning temperature effects.

\section{FUTURE WORK}

Ongoing experiments involving 2.3-g plutonium oxide sources in fresh water environments show distinct maxima in the plutonium concentrations between 6 to 10 weeks after introducing the sources into the water. This behavior occurred in past experiments as well. ${ }^{3}$ Because the present experiment was too short to reveal this behavior. if it occurred, future experiments should be continued for 2 to 3 months. Better characterization of the released plutonium species, both in terms of filtration methods and oxidation-state determination. could yield information that may prove invaluablc in elucidating release mechanisms.

The current experiment was carried out by using a constant sample mass with a varying surface area. A complete experimental design would require the converse experiment, one with constant surface area and varying mass. Such an experiment, conducted over a longer time with the improved characterization metn- ods called for above. would complete the study of surface area and mass effects and also provide some fundamental data about release mechanisms.

The higher temperaturc cxperiments should be repeated with the sampling done at temperature to avoid ihe uncertainties caused by the hypothesized convection zurrents in the sample containers.

\section{REFERENCES}

1. R. C. Heaton. J. H. Patterson. P. Wagner and L. W. Wangen. "Experimental Plan of Plutonium Environmental Studies," Los Alamos National Laboratory document (August 10. 1983).

2. J. H. Patterson. F. J. Steinkruger. G. M. Matlack. R. C. Heaton, K. P. Coffelt, and B. Herrera. "Plutonium Release from Pressed Plutonium Oxide Fucl Pellets in Aquatic Environments." Los Alamos National Laboratory report LA-9962-MS (December 1983).

3. R. C. Heaton, J. H. Patterson, S. T. Kosicwicz, G. M. Matlack. F. J. Steinkruger, G. B. Nelson, N. E. Vanderborgh, K. P. Coffelt. and B. Herrera, "LongTerm Exposure of Pressed Plutonium Oxide Heat Sources to Aquatic Environments." Los Alamos National Laboratory report LA-10197-MS (November 1984). 
4. J. H. Patterson, G. B. Nelson, and G. M. Matlack, "The Dissolution of ${ }^{238} \mathrm{Pu}$ in Environmental and Biological Systems," Los Alamos Scientific Laboratory report LA-5624 (July 1974).

5. G. M. Matlack, J. H. Patterson, G. B. Nelson, and G. R. Waterbury, "Dissolution Rates of ${ }^{238} \mathrm{PuO}_{2}$ and ${ }^{239} \mathrm{PuO}_{2}$ in $1 \mathrm{M}$ Perchloric Acid," Los Alamos Scientific Laboratory report LA-6184 (March 1976).
6. F. W. Clinard, Jr., and D. L. Rohr, "Spontaneous Fragmentation of an Alpha-Active Ceramic-A Mechanism for Dispersion of Solid Waste?" in Scientific Basis for Nuclear Waste Management, Vol. 3, J. C. Moore, Ed. (Plenum Publishing Corporation, 1981), pp. 405-4! 2 . 